\title{
The importance of disclosure in corporate governance self-regulation across Europe: A review of the Winter Report and the EU Action Plan
}

\author{
Gregory F. Maassen, Frans A. J. van den Bosch and Henk Volberda \\ Received: 22nd October, 2003 \\ Erasmus University, Rotterdam School of Management, Burgemeester Oudlaan 50, P.O. Box 1738, \\ 3000 DR Rotterdam, The Netherlands; Tel: +31 (0)10 4082210; E-mail: gmaassen@mktaal.nl
}

Gregory F. Maassen specialises in Technical Assistance Projects in the field of economic law reform and corporate governance in transitional economies.

He was a senior corporate governance specialist at the International Finance Corporation of the World Bank Group with working experience in Armenia (three years as a corporate governance project manager), Georgia, Uzbekistan, Indonesia, Azerbaijan, Mongolia, Kazakhstan, Ukraine and Russia. He is currently working as the Project Manager of the Macedonia Corporate Governance and Company Law Project of Deloitte Touche Tohmatsu/USAID in Skopje. In addition, he is a research consultant for Spencer Stuart European Board Practices (editor of Spencer Stuart Board Indexes) and an assistant professor at Rotterdam School of Management, Erasmus University in the Netherlands where he teaches MBA courses on corporate governance and strategic management. He wrote his dissertation (1999) on international corporate-governance models.

Frans A. J. van den Bosch is a professor of management at the Department of Strategic Management and Business Environment, Rotterdam School of Management, Erasmus University, Rotterdam. He holds a master's degree (cum laude) in economics from the Erasmus University, Rotterdam and a PhD in law from Leyden University. His current research interests include managerial and knowledge-based theories of the firm, strategic renewal, intra and interorganisational governance structures, corporate governance and corporate responsiveness. He has published several books and papers in journals such as the Journal of Management Studies, Long Range Planning, Organization Science, Organization Studies and Business and Society. $\mathrm{He}$ is co-director of the Erasmus Strategic Renewal Center (ESRC) and of the research program 'Managing Strategic Renewal of Multiunit Firms and Networks in Turbulent International Environments' of the Erasmus Research Institute of Management (ERIM).

Henk W. Volberda is a professor of strategic management and business policy and Chairman of the Department of Strategic Management and Business Environment, Rotterdam School of Management, Erasmus University, Rotterdam. In 1992, he earned his PhD cum laude in business administration from the University of Groningen. For his research on strategic flexibility, he received several awards including the Igor Ansoff Award 1993. His research interests include strategic flexibility, new organisational forms and strategic management of innovation. He has published in journals such as the Journal of Management Studies, Long Range Planning, Organization Science, Organization Studies and Omega.

He has published a book on 'Building the 
Flexible Firm: How to Remain Competitive', Oxford University Press (1998) and one with Sage (2001) on 'Rethinking Strategy'. He is Codirector of the Erasmus Strategic Renewal Center (ESRC) and of the research program 'Managing Strategic Renewal of Multiunit Firms and Networks in Turbulent International Environments' of the Erasmus Research Institute of Management (ERIM). He is currently studying the process of strategic renewal within large European corporations. Moreover, he is senior editor of JIBS and LRP, editor in chief of M\&O and Management Select, and editor of Organization Science and MAB.

\section{ABSTRACT \\ KEYWORDS: Winter Report, self-regula- tion, corporate-governance codes, inter- national standards and regulatory forms, board disclosure in Europe}

Although self-regulation has proven to be effective for the development of voluntary corporate-governance codes, the results of this study indicate that leading European companies are not yet too concerned about compliance with these codes. While self-regulation appears to be ineffective to change the disclosure practices of companies, the study concludes that factors relevant for choosing regulatory forms and the impact and risks involved with non-compliance of companies with voluntary codes have determined the Winter Report's emphasis on selfregulation.

\section{INTRODUCTION}

Triggered by financial irregularities in the USA, and partly in response to the extraterritorial implications of the Sarbanes-Oxley Act, the European Union (EU) responded in 2002 with the publication of the Winter Report of the High Level Group of Company Law Experts. ${ }^{1}$ One year later, the EU has initiated a public debate on its corporate governance Action Plan based on the Winter Report. ${ }^{2}$ The report emphasises the importance of voluntary disclosure by boards of directors to avoid financial scandals and to boost investor confidence in EU member states. Although the Winter Report underlines the importance of voluntary codes of conduct, critics seem to be well positioned to question the effectiveness of these codes on board behaviour and disclosure.

This paper reviews the introduction of voluntary codes across Europe as part of a greater global development by financial markets to effect changes in the structure and behaviour of boards of directors. By analysing the level of board disclosure of 483 listed corporations in 12 countries (eight EU member states and four nonEU countries), this paper reviews the impact of more than ten years of corporate governance codes across Europe. The paper concludes that, despite years of self-regulation, disclosure levels continue to differ greatly across Europe. In spite of the limited impact corporate governance codes seem to have had on board practices, the small risks associated with non-compliance seem to justify the role voluntary codes of conduct play in improving investor confidence.

\section{THE WINTER REPORT}

While most media attention was directed at the introduction of the Sarbanes-Oxley Act in the USA, Chairman Jaap Winter of the High Level Group of Company Law Experts presented a report on a 'Modern Regulatory Framework for Company Law in Europe' to EU Commissioner Frits Bolkestein on 4th November, 2002. This important report for regulators in the EU did not receive much attention from the media or from corporate governance experts outside Europe. This was remarkable, since this report has been used as the basis for the EU action plan for corporate governance published in May 2003.

The Winter Report and the EU action plan display great confidence in the effectiveness of self-regulation in corporate governance to enforce stricter disclosure 
requirements across the EU. More specifically, the Winter Report states:

'Disclosure can be a powerful regulatory tool: it creates an incentive to comply with best practice, and allows members and third parties to take necessary actions. Disclosure requirements can be more efficient, more flexible and easier to enforce."

The report reviews a great number of issues related to the corporate governance practices of Europe's leading companies. Through the use of national voluntary codes of conduct and the enforcement of standards of conduct on a 'comply or explain' basis at a minimum, the Winter Report recommends that listed companies disclose more information on the role of non-executive and supervisory directors, management remuneration, the responsibility of management for financial statements and auditing practices. Table 1 summarises most of the Winter Report's recommendations to improve the disclosure practices of boards of directors of listed corporations.

\section{SELF-REGULATION AND CORPORATE GOVERNANCE}

The emphasis of the Winter Report on voluntary disclosure is not new to most financial markets. Self-regulation has been favoured by most international financial markets to develop and implement modern corporate governance standards. According to the European Corporate Governance Institute, more than 107 codes, including revisions of existing codes, have been introduced since 1992 in 35 countries. ${ }^{4}$ In Europe alone, more than 55 codes have been introduced in 19 countries. ${ }^{5}$

The early self-regulation initiatives in the UK have had a tremendous impact on the development of corporate governance standards in other European countries and across the globe (see Figures 1 and 2).
The globalisation of self-regulation can be categorised by four distinctive phases: the first phase, modern code development, began in the UK with the introduction of the Cadbury Code in $1992 .^{7}$

Subsequent to the developments in the UK, the second phase occurred between 1994 and 1996, dominated by the development of codes of best practices mainly in other Anglo-Saxon jurisdictions; codes that were heavily influenced by the publication of the Cadbury Code and the Greenbury Report. ${ }^{8}$ In France, however, as one of the first continental European countries to develop a code, the 1995 Viénot Report recommended that directors reduce the number of cross-directorships and suggested the appointment of at least two independent directors to boards of listed corporations; ${ }^{9}$ soon afterwards, in October 1996, the Círculo de Empresarios was introduced in Spain. ${ }^{10}$

During the third phase in the globalisation of corporate governance standards (19972000), further continental European countries introduced codes of best practice. These included the Dutch Peters Report in 1997; the Belgian Cardon Report in 1998; the Viénot II Report in 1999; the recent Swiss Code of Best Practice; and many others. ${ }^{11}$ Following the Asian financial crisis, voluntary codes were introduced to financial markets across the continent, including in Japan with the Keidanrein Report in 1997; the CII's Corporate Governance Code in India in 1999; the Korean Committee on Corporate Governance in 1999; and the Malaysian Report on Corporate Governance in 2000. ${ }^{12}$ In Indonesia, the National Committee on Corporate Governance published a draft version of the Indonesian Code of Good Corporate Governance in 2000, which was updated in 2001. ${ }^{13}$

As part of the fourth phase, and mainly under the influence of the Organisation for Economic Cooperation and Development (OECD), the United States Agency for International Development (USAID), the 
Table 1: Winter Report: Overview of recommendations

\begin{tabular}{|c|c|c|}
\hline Issue & Recommendations of the Winter Report & Section \\
\hline Disclosure & $\begin{array}{l}\text { The EU, in considering new - and amending existing - regulations or } \\
\text { company law, should carefully consider whether disclosure requirements are } \\
\text { better suited to achieve the desired effects than substantive rules. Any } \\
\text { disclosure requirement should be based on the obligation to provide fair, } \\
\text { relevant and meaningful information. }\end{array}$ & II. 3 \\
\hline $\begin{array}{l}\text { New } \\
\text { Technology }\end{array}$ & $\begin{array}{l}\text { Listed companies should be required to maintain and continuously update a } \\
\text { company information section on their websites, and maintain links with } \\
\text { public registers and other relevant authorities. }\end{array}$ & II.6 \\
\hline $\begin{array}{l}\text { Corporate } \\
\text { Governance } \\
\text { Statement }\end{array}$ & $\begin{array}{l}\text { Listed companies should be required to include in their annual report and } \\
\text { accounts a coherent and descriptive statement covering the key elements of } \\
\text { the corporate governance rules and practices to which they apply. This } \\
\text { statement should also be separately posted on the company's website. Such a } \\
\text { statement should contain a reference to the designated national code of } \\
\text { corporate governance and/or company law rules with which the company } \\
\text { complies or in relation to which it explains deviations. }\end{array}$ & III.1 \\
\hline Independence & $\begin{array}{l}\text { Listed companies should be required to disclose in their annual corporate } \\
\text { governance statement which of their directors they consider to be } \\
\text { independent and on what grounds. Similar disclosure should be made } \\
\text { when a new director is proposed for appointment. }\end{array}$ & III.10 \\
\hline Composition & $\begin{array}{l}\text { Listed companies should include in their annual corporate governance } \\
\text { statement a profile of the board's composition, and they should explain why } \\
\text { individual non-executive or supervisory directors are qualified to serve on } \\
\text { the board in their particular roles. Similar disclosure should be made in } \\
\text { proposals for initial appointment. }\end{array}$ & III.10 \\
\hline Interlocks & $\begin{array}{l}\text { Listed companies should be required to disclose what board positions in } \\
\text { other companies their non-executive or supervisory directors hold. }\end{array}$ & III.10 \\
\hline Remuneration & $\begin{array}{l}\text { The remuneration policy for directors generally should be disclosed in the } \\
\text { financial statements of the company, and should be an explicit item for } \\
\text { debate on the agenda of the annual meeting. The individual remuneration of } \\
\text { directors of the company, both executive and non-executive or supervisory } \\
\text { directors, is to be disclosed in detail in the financial statements of the } \\
\text { company. } \\
\text { Schemes granting shares and share options and other forms of } \\
\text { remuneration of directors linked to the share price should require the } \\
\text { prior approval of the shareholders meeting, on the basis of a proper } \\
\text { explanation by the remuneration committee of the applicable rules and of } \\
\text { their likely costs. } \\
\text { The costs of all share-incentive schemes should be properly reflected in } \\
\text { the annual accounts, and this accounting principle should be recognised in a } \\
\text { European framework rule. }\end{array}$ & III.11 \\
\hline
\end{tabular}


Figure 1: Phases in the globalisation of corporate governance standards ${ }^{6}$

\begin{tabular}{|c|c|c|c|}
\hline $\begin{array}{c}\text { Phase 1 } \\
1992-1993\end{array}$ & $\begin{array}{c}\text { Phase 2 } \\
1994-1996\end{array}$ & $\begin{array}{c}\text { Phase } 3 \\
1997-2000\end{array}$ & $\begin{array}{c}\text { Phase } 4 \\
2001-\end{array}$ \\
\hline $\begin{array}{l}\text { Cadbury } \\
\text { Code } 1992\end{array}$ & $\begin{array}{l}\text { Greenbury } \\
\text { Report } 1995\end{array}$ & $\begin{array}{c}\text { Hampel } \\
\text { and Turnbull } \\
1998 / 1999\end{array}$ & $\begin{array}{l}\text { DTI Law } \\
\text { Review } \\
2001\end{array}$ \\
\hline $\begin{array}{l}\text { The first code of } \\
\text { best practices on } \\
\text { corporate } \\
\text { governance } \\
\text { introduced in the } \\
\text { UK }\end{array}$ & $\begin{array}{l}\text { Anglo-Saxon } \\
\text { countries are the } \\
\text { first to follow, } \\
\text { including some } \\
\text { initiatives in } \\
\text { continental } \\
\text { European countries }\end{array}$ & $\begin{array}{l}\text { The majority of } \\
\text { continental } \\
\text { European countries } \\
\text { and a few countries } \\
\text { in Asia and South } \\
\text { America follow } \\
\text { with the } \\
\text { introduction of } \\
\text { voluntary standards }\end{array}$ & $\begin{array}{c}\text { Developing } \\
\text { countries start to } \\
\text { embark on } \\
\text { corporate } \\
\text { governance through } \\
\text { the development of } \\
\text { legislation and } \\
\text { codes }\end{array}$ \\
\hline
\end{tabular}

Figure 2: The globalisation of corporate governance standards ${ }^{14}$

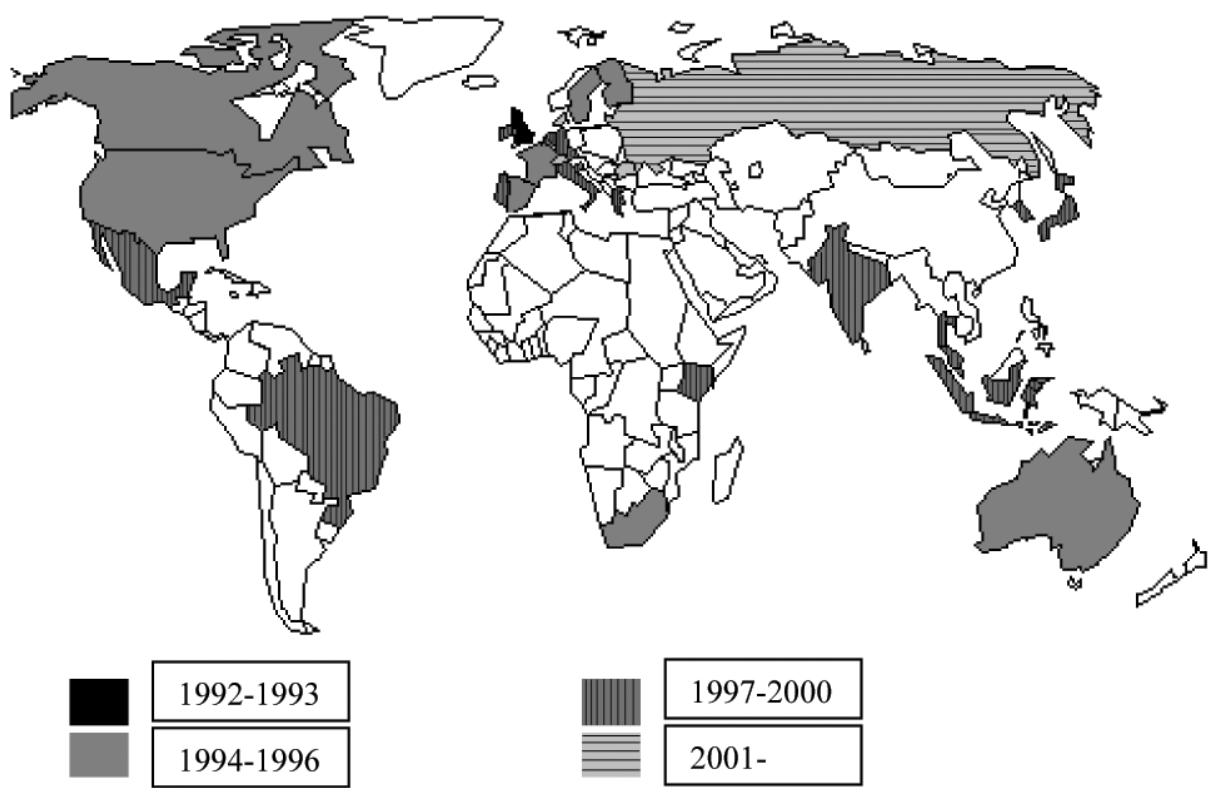

European Bank for Reconstruction and Development (EBRD) and the International Finance Corporation (IFC; part of the World Bank Group), Russia and other eastern European countries started the development of corporate-governance standards. ${ }^{15}$ The modernisation of corporation laws in the former Soviet Union began in 1996 with the enactment of the new Russian Law on
Joint Stock Companies. The Russian Corporate Governance Code was introduced in April 2002, four months after the Russian Federation significantly amended its Law on Joint Stock Companies. ${ }^{16}$ In June 2002, Poland also completed its final draft of the 'Corporate Governance Code for Listed Polish Corporations'; countries in the Balkans are modernising their company 
laws with the assistance of the USA and the EU. ${ }^{17}$

Meanwhile, the private sector in the UK appears to have embarked on a new round of self-regulatory initiatives with the publication of the Smith Report on audit committees, the Higgs Report on the role and effectiveness of non-executive directors and the Combined Code on Corporate Governance in $2003 .{ }^{18}$ Given the popularity of these codes, more national codes can be expected in the near future.

\section{PAN-EUROPEAN CORPORATE GOVERNANCE CODES}

Although Europe witnessed some attempts to establish pan-European codes of corporate governance, such as the OECD principles on corporate governance, ${ }^{19}$ it appears to be unlikely that a pan-European code will be introduced by the EU, in line with the recommendations of the Winter Report. According to the drafters of the Winter Report:

'The adoption of such a code would not achieve full information for investors about the key corporate governance rules applicable to companies across Europe, as these rules would still be based on and part of national company laws that are in certain aspects widely divergent. We also doubted whether additional Europe-wide voluntary rules would contribute to the improvement of corporate governance, as Europe would either have to allow many alternative rules, depending on the various company law systems, or to confine itself to abstract, and perhaps largely meaningless, rules which would be compatible with all of these systems. ${ }^{, 20}$

\section{DETERMINANTS OF EFFECTIVE VOLUNTARY DISCLOSURE}

The confidence of the Winter Report in disciplining markets with voluntary disclosure is not shared by all academics and market observers who have been reporting on deficiencies of capital markets' protection of shareholders. Cuervo pleads for fewer codes of corporate governance and more market control. ${ }^{21}$ These authors believe that the absence of an effective corporate-control market that disciplines controlling shareholders; the weakness of institutional investors; ${ }^{22}$ and the widespread adoption of managerial defence mechanisms ${ }^{23}$ are major barriers preventing minority shareholders from exercising their rights.

Besides these market constraints, criticism is also directed at the effectiveness of selfregulation as a mechanism to set and enforce corporate governance standards. Whittington indicates that self-regulation has an enforcement problem when new standards conflict with the interests of parties involved. ${ }^{24}$ As stated more profoundly by Finch:

'Self-regulatory structures are prone to a number of criticisms - that, for instance, they favour the regulated group and ignore the broader public interest; they are designed with large, well-organised, well-resourced enterprises in mind and fail to deal with those who really need to be regulated; their procedures tend to exclude third parties; they are low on accountability; they have anti-competitive effects; they tend not to enjoy public confidence; and their investigative, enforcement and sanctioning processes tend to be weak. ${ }^{25}$

The criticism related to the effectiveness of self-regulation in corporate governance has not been well supported by the limited number of studies on the impact of voluntary codes of conduct on the corporate governance practices of corporations. The authors of this paper could find only a few impact assessments and monitoring reports on the implementation of voluntary codes. ${ }^{26}$ But more troublesome for proponents of voluntary corporate governance standards seems to be the inconclusive evidence on 
the relationship between the implementation of corporate governance standards and the performance of corporations. Interestingly, there appears to be an increasing awareness that the conventional corporate governance interventions proposed by most corporate governance codes are not necessarily positively associated with the performance of corporations. ${ }^{27}$

As an example, most corporate governance codes promote the independence of boards of directors. Not only do the definitions of independent boards vary widely; a positive relationship with the performance of corporations is difficult to claim. To illustrate this, Bhagat and Black state:

'At the very least there is no convincing evidence that increasing board independence, relative to the norms that currently prevail among large American firms, will improve firm performance. And there is some evidence suggesting the opposite that firms with supermajority-independent boards perform worse than other firms, and that firms with more inside than independent directors perform about as well as firms with majority- (but not supermajority-) independent boards. ${ }^{28}$

\section{RESEARCH APPROACH}

This study has not attempted to measure the relationship between the implementation of corporate governance standards and the financial performance of corporations. Nor has it measured the impact on shareholder confidence of specific voluntary corporate governance codes in particular countries.

Instead, this study reviewed the quantity of information companies disclosed about their boards of directors in their 2001 annual reports. Its authors reviewed a total of 483 annual reports of listed companies in 12 European countries (see Table 2). In particular, the study collected basic information on the number of board meetings, the composition of the board of directors, the
Table 2: Number of companies

\begin{tabular}{lcc}
\hline Country & $\begin{array}{l}\text { Number of } \\
\text { companies }\end{array}$ & $\begin{array}{l}\text { Percentage of } \\
\text { total }\end{array}$ \\
\hline Belgium & 20 & 4.1 \\
Czech Republic & 16 & 3.3 \\
France & 39 & 8.1 \\
Germany & 30 & 6.2 \\
Italy & 27 & 5.6 \\
Netherlands & 100 & 20.7 \\
Poland & 14 & 2.9 \\
Russia & 10 & 2.1 \\
Spain & 31 & 6.4 \\
Sweden & 21 & 4.3 \\
Switzerland & 25 & 5.2 \\
United Kingdom & 150 & 31.1 \\
Total: & 483 & 100.0 \\
\hline
\end{tabular}

use of board committees and the leadership structure of the board. In addition, the authors reviewed the amount of information disclosed on the remuneration and demographic information of 4,995 individual directors occupying a total of 6,093 board positions in the companies surveyed. A majority, 305 companies (63 per cent), have a one-tier board. The remaining 178 companies (37 per cent) have a board of directors based on a two-tier structure (see Table 3).

\section{FINDINGS}

This study examined the disclosure of information on board demographics and the tenure of directors (see Table 4). Few companies (28.8 per cent) disclose the nationality of their directors. Less than half of the total number of directors have their tenure with the company disclosed (49.5 per cent). Age is disclosed for 62.7 per cent of directors. Of the data examined, the gender of directors is most often indicated in annual reports (98.5 per cent).

Companies also seemed to resist disclosing the number of meetings their boards of directors had held in 2001 (see Table 5); onethird of the companies ( 33.3 per cent) did not 
Table 3: Number of directors and their positions in boards

\begin{tabular}{llrlrlr}
\hline Countries & Directors & \multicolumn{3}{l}{ Positions } & \multicolumn{2}{l}{ Companies } \\
\hline 12 & Males: & 4,637 & Executive: & 1,883 & One-Tier Boards: & 305 \\
& Females: & 270 & Non-Executive: & 4,122 & Two-Tier Boards: & 178 \\
& Unknown: & 88 & Unknown: & 88 & & \\
Total: & 4,995 & Total: & 6,093 & Total: & 483 \\
\hline
\end{tabular}

Table 4: Disclosure of demographics and tenure

\begin{tabular}{lcrlrrrrrr}
\hline Country & $\begin{array}{l}\text { Number of } \\
\text { positions }\end{array}$ & $\begin{array}{l}\text { Disclosure of } \\
\text { nationality }\end{array}$ & $\begin{array}{l}\text { Disclosure of } \\
\text { gender }\end{array}$ & \multicolumn{2}{l}{$\begin{array}{l}\text { Disclosure of } \\
\text { age }\end{array}$} & $\begin{array}{l}\text { Disclosure of } \\
\text { tenure }\end{array}$ \\
\hline Belgium & 271 & 59 & $21.8 \%$ & 264 & $97.4 \%$ & 145 & $53.5 \%$ & 98 & $36.2 \%$ \\
Czech Republic & 221 & 190 & 86.0 & 221 & 100.0 & 102 & 46.2 & 63 & 28.5 \\
France & 603 & 172 & 28.5 & 594 & 98.5 & 420 & 69.7 & 279 & 46.3 \\
Germany & 733 & 47 & 6.4 & 732 & 99.9 & 300 & 40.9 & 226 & 30.8 \\
Italy & 384 & 4 & 1.0 & 372 & 96.9 & 34 & 8.9 & 7 & 1.8 \\
Netherlands & 896 & 711 & 79.4 & 844 & 94.2 & 803 & 89.6 & 571 & 63.7 \\
Poland & 200 & 130 & 65.0 & 200 & 100.0 & 13 & 6.5 & 9 & 4.5 \\
Russia & 226 & 212 & 93.8 & 223 & 98.7 & 44 & 19.5 & 24 & 10.6 \\
Spain & 453 & 8 & 1.8 & 452 & 99.8 & 38 & 8.4 & 80 & 17.7 \\
Sweden & 256 & 18 & 7.0 & 254 & 99.2 & 203 & 79.3 & 185 & 72.3 \\
Switzerland & 224 & 76 & 33.9 & 224 & 100.0 & 120 & 53.6 & 52 & 23.2 \\
United Kingdom & 1,626 & 129 & 7.9 & 1,623 & 99.8 & 1,600 & 98.4 & 1,419 & 87.3 \\
Total: & 6,093 & 1,756 & $28.8 \%$ & 6,003 & $98.5 \%$ & 3,822 & $62.7 \%$ & 3,013 & $49.5 \%$ \\
\hline
\end{tabular}

Table 5: Disclosure of board committees and board meetings

\begin{tabular}{|c|c|c|c|c|c|c|c|}
\hline \multirow{2}{*}{$\begin{array}{l}\text { Country } \\
\text { Belgium }\end{array}$} & \multirow{2}{*}{$\begin{array}{l}\begin{array}{l}\text { Number of } \\
\text { companies }\end{array} \\
20\end{array}$} & \multirow{2}{*}{$\begin{array}{c}\text { Number of } \\
\text { committees }\end{array}$} & \multirow{2}{*}{$\begin{array}{c}\text { Number of } \\
\text { positions }\end{array}$} & \multicolumn{2}{|c|}{$\begin{array}{l}\text { Disclosure of } \\
\text { committee } \\
\text { meetings }\end{array}$} & \multicolumn{2}{|c|}{$\begin{array}{l}\text { Disclosure of } \\
\text { board } \\
\text { meetings }\end{array}$} \\
\hline & & & & 22 & $41.5 \%$ & 19 & $95.0 \%$ \\
\hline Czech Republic & 16 & 17 & 221 & 0 & 0.0 & 1 & 6.3 \\
\hline France & 39 & 100 & 603 & 70 & 70.0 & 28 & 71.8 \\
\hline Germany & 30 & 86 & 733 & 49 & 57.0 & 28 & 93.3 \\
\hline Italy & 27 & 53 & 384 & 17 & 32.1 & 14 & 51.9 \\
\hline Netherlands & 100 & 163 & 896 & 52 & 31.9 & 83 & 83.0 \\
\hline Poland & 14 & 14 & 200 & 0 & 0.0 & 0 & 0.0 \\
\hline Russia & 10 & 14 & 226 & 0 & 0.0 & 1 & 10.0 \\
\hline Spain & 31 & 87 & 453 & 32 & 36.8 & 21 & 67.7 \\
\hline Sweden & 21 & 39 & 256 & 9 & 23.1 & 17 & 81.0 \\
\hline Switzerland & 25 & 63 & 224 & 5 & 7.9 & 10 & 40.0 \\
\hline United Kingdom & 150 & 574 & 1,626 & 179 & 31.2 & 100 & 66.7 \\
\hline Total: & 483 & 1,263 & 6,093 & 435 & $25.5 \%$ & 322 & $66.7 \%$ \\
\hline
\end{tabular}


Table 6: Disclosure of remuneration of non-executive directors

\begin{tabular}{|c|c|c|c|c|c|c|c|c|c|}
\hline \multirow{2}{*}{$\begin{array}{l}\text { Country } \\
\text { Belgium }\end{array}$} & \multirow{2}{*}{$\begin{array}{l}\text { Number of } \\
\text { non-executive } \\
\text { positions }\end{array}$} & \multicolumn{2}{|c|}{$\begin{array}{l}\text { Disclosure of } \\
\text { individual } \\
\text { remuneration }\end{array}$} & \multicolumn{2}{|c|}{$\begin{array}{l}\text { Disclosure of } \\
\text { chairman } \\
\text { remuneration }\end{array}$} & \multicolumn{2}{|c|}{$\begin{array}{l}\text { Disclosure of } \\
\text { independent } \\
\text { member } \\
\text { remuneration }\end{array}$} & \multicolumn{2}{|c|}{$\begin{array}{l}\text { Disclosure of } \\
\text { common } \\
\text { member } \\
\text { remuneration }\end{array}$} \\
\hline & & 20 & $9.3 \%$ & 1 & $8.3 \%$ & 7 & $8.8 \%$ & 19 & $9.8 \%$ \\
\hline Czech Republic & 131 & 0 & 0.0 & 0 & 0.0 & 0 & 0.0 & 0 & 0.0 \\
\hline France & 475 & 185 & 38.9 & 5 & 33.3 & 63 & 57.8 & 175 & 39.5 \\
\hline Germany & 527 & 0 & 0.0 & 0 & 0.0 & 0 & 0.0 & 0 & 0.0 \\
\hline Italy & 293 & 136 & 46.4 & 4 & 66.7 & 48 & 51.1 & 126 & 46.0 \\
\hline Netherlands & 546 & 114 & 20.9 & 13 & 13.7 & 0 & 0.0 & 93 & 22.0 \\
\hline Poland & 112 & 0 & 0.0 & 0 & 0.0 & 0 & 0.0 & 0 & 0.0 \\
\hline Russia & 111 & 5 & 4.5 & 1 & 12.5 & 0 & 0.0 & 4 & 4.1 \\
\hline Spain & 381 & 7 & 1.8 & 0 & 0.0 & 0 & 0.0 & 6 & 1.7 \\
\hline Sweden & 228 & 19 & 8.3 & 5 & 38.5 & 0 & 0.0 & 11 & 5.6 \\
\hline Switzerland & 184 & 7 & 3.8 & 0 & 0.0 & 0 & 0.0 & 6 & 3.8 \\
\hline United Kingdom & 920 & 809 & 87.9 & 86 & 91.5 & 595 & 91.5 & 672 & 87.2 \\
\hline Total: & 4,122 & 1,302 & $31.6 \%$ & 115 & $35.7 \%$ & 713 & $68.2 \%$ & 1,112 & $31.3 \%$ \\
\hline
\end{tabular}

disclose the number of board meetings. Most of the companies surveyed in Belgium did disclose information about the number of board meetings held (95 per cent). Onefourth of the companies (25.5 per cent) disclosed the number of meetings of board committees. French companies were leaders in disclosing information about these meetings (70 per cent).

The disclosure of the individual remuneration of non-executive directors, as opposed to total remuneration of the entire board, is most frequently observed in the UK, Italy, France and the Netherlands. Although the first steps have been made by companies in other countries, individual remuneration of non-executive directors is disclosed for just 31.6 per cent of the directors in the study. The individual remuneration of independent non-executive directors is on average more often disclosed than for other non-executive directors (see Table 6).

The disclosure of the individual remuneration of executive directors is again most frequently observed in the UK, Italy, France and the Netherlands. The individual remuneration of executive directors is disclosed for 44 per cent of the directors in the study. The individual remuneration of chief executive officers is on average more often disclosed than that of other executive directors (see Table 7).

Across Europe, the independence of nonexecutive directors is disclosed by less than one-third of the companies reviewed (32.9 per cent), including directors who have been classified as non-independent in annual reports. The greatest level of disclosure of the independence of directors is found in the UK, Belgium, Italy and France. This study could not find any indication of the disclosure of the independence of nonexecutive directors in the Czech Republic, Germany, Poland or Russia (see Table 8).

\section{THE WINTER REPORT AND THE FINDINGS OF THIS STUDY}

The level of corporate governance disclosure in the annual reports of companies across Europe included in this study appears to be 
Table 7: Disclosure of remuneration of executive directors

\begin{tabular}{|c|c|c|c|c|c|c|c|c|c|}
\hline \multirow{2}{*}{$\begin{array}{l}\text { Country } \\
\text { Belgium }\end{array}$} & \multirow{2}{*}{$\begin{array}{l}\text { Number of } \\
\text { executive } \\
\text { positions }\end{array}$} & \multicolumn{2}{|c|}{$\begin{array}{l}\text { Disclosure of } \\
\text { individual } \\
\text { remuneration }\end{array}$} & \multicolumn{2}{|c|}{$\begin{array}{l}\text { Disclosure of } \\
\text { chairman } \\
\text { remuneration }\end{array}$} & \multicolumn{2}{|c|}{$\begin{array}{l}\text { Disclosure of } \\
\text { CEO } \\
\text { remuneration }\end{array}$} & \multicolumn{2}{|c|}{$\begin{array}{l}\text { Disclosure of } \\
\text { common } \\
\text { member } \\
\text { remuneration }\end{array}$} \\
\hline & & 0 & $0.0 \%$ & 0 & $0.0 \%$ & 0 & $0.0 \%$ & 0 & $0.0 \%$ \\
\hline Czech Republic & 90 & 0 & 0.0 & 0 & 0.0 & 0 & 0.0 & 0 & 0.0 \\
\hline France & 107 & 29 & 27.1 & 12 & 36.4 & 10 & 34.5 & 15 & 24.6 \\
\hline Germany & 206 & 0 & 0.0 & 0 & 0.0 & 0 & 0.0 & 0 & 0.0 \\
\hline Italy & 60 & 29 & 48.3 & 9 & 60.0 & 8 & 47.1 & 9 & 39.1 \\
\hline Netherlands & 350 & 114 & 32.6 & 23 & 43.4 & 9 & 20.9 & 80 & 31.9 \\
\hline Poland & 88 & 0 & 0.0 & 0 & 0.0 & 0 & 0.0 & 0 & 0.0 \\
\hline Russia & 115 & 8 & 7.0 & 0 & 0.0 & 1 & 16.7 & 7 & 7.6 \\
\hline Spain & 65 & 1 & 1.5 & 0 & 0.0 & 1 & 5.6 & 0 & 0.0 \\
\hline Sweden & 22 & 7 & 31.8 & 1 & 33.3 & 7 & 35.0 & 0 & 0.0 \\
\hline Switzerland & 21 & 0 & 0.0 & 0 & 0.0 & 0 & 0.0 & 0 & 0. \\
\hline United Kingdom & 703 & 641 & 91.2 & 50 & 94.3 & 127 & 93.4 & 462 & 90.1 \\
\hline Total: & 1,883 & 829 & $44.0 \%$ & 95 & $38.5 \%$ & 163 & $50.9 \%$ & 573 & $44.4 \%$ \\
\hline
\end{tabular}

Table 8: Disclosure of the independence of non-executive directors

\begin{tabular}{|c|c|c|c|c|c|c|}
\hline \multirow{2}{*}{$\begin{array}{l}\text { Country } \\
\text { Belgium }\end{array}$} & \multirow{2}{*}{$\begin{array}{l}\text { Number of } \\
\text { non-executive } \\
\text { positions }\end{array}$} & \multicolumn{2}{|c|}{$\begin{array}{l}\text { Independent } \\
\text { non-executives }\end{array}$} & \multicolumn{2}{|c|}{$\begin{array}{l}\text { Non-independent } \\
\text { non-executives }\end{array}$} & \multirow{2}{*}{$\begin{array}{l}\text { Dependency } \\
\text { disclosed }\end{array}$} \\
\hline & & 80 & $37.4 \%$ & 73 & $34.1 \%$ & \\
\hline Czech Republic & 131 & 0 & 0.0 & 0 & 0.0 & 0.0 \\
\hline France & 475 & 109 & 22.9 & 85 & 17.9 & 40.8 \\
\hline Germany & 527 & 0 & 0.0 & 0 & 0.0 & 0.0 \\
\hline Italy & 293 & 94 & 32.1 & 48 & 16.4 & 48.5 \\
\hline Netherlands & 546 & 11 & 2.0 & 0 & 0.0 & 2.0 \\
\hline Poland & 112 & 0 & 0.0 & 0 & 0.0 & 0.0 \\
\hline Russia & 111 & 0 & 0.0 & 0 & 0.0 & 0.0 \\
\hline Spain & 381 & 64 & 16.8 & 24 & 6.3 & 23.1 \\
\hline Sweden & 228 & 14 & 6.1 & 1 & 0.4 & 6.6 \\
\hline Switzerland & 184 & 23 & 12.5 & 2 & 1.1 & 13.6 \\
\hline United Kingdom & 920 & 650 & 70.7 & 79 & 8.6 & 79.2 \\
\hline Total: & 4,122 & 1,045 & $25.4 \%$ & 312 & $7.6 \%$ & $32.9 \%$ \\
\hline
\end{tabular}

limited, despite the more than 50 corporate governance guidelines that have been introduced in Europe since 1992. This raises the intriguing question of why the 'High Level Group of Company Law Experts' responsible for drafting the Winter Report emphasised the effectiveness of self-regulation and dis- closure. Why do these experts leave the development of corporate governance standards for boards of directors in the EU to the market? Why do they emphasise self-regulation, when self-regulatory structures are criticised and evidence on the impact of self-regulation is limited? 
Figure 3: Risk and impact of non-compliance with voluntary corporate governance codes ${ }^{31}$

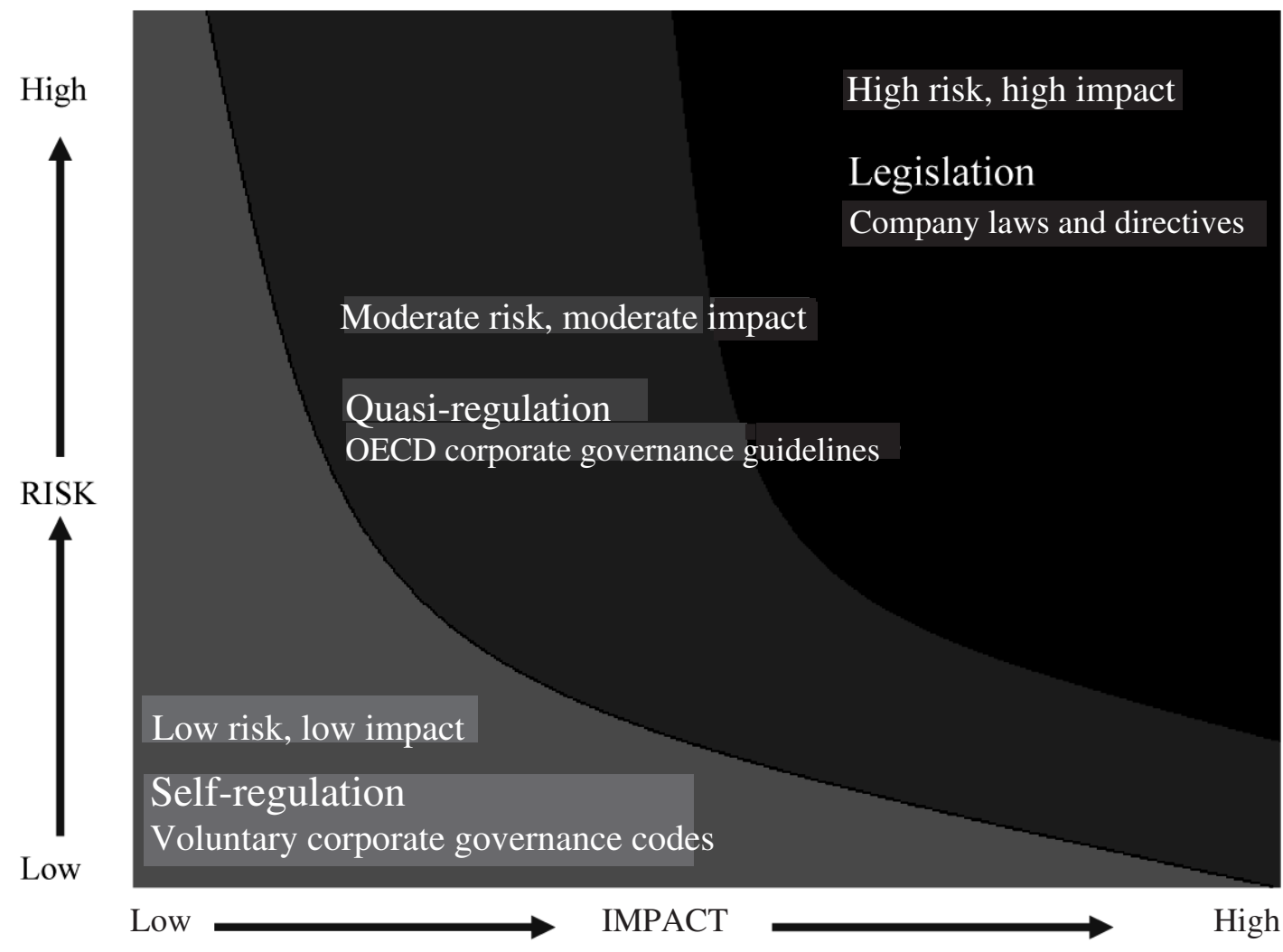

The answer can be found in the factors that are relevant for choosing regulatory forms such as self-regulation, quasi-regulation and legislation ('black-letter law') and the impact and risks involved with non-compliance with voluntary corporate governance codes.

\section{FACTORS RELEVANT FOR CHOOSING REGULATORY FORMS}

Two main factors, among others, seem to be relevant for choosing regulatory forms or government interventions through legislation to improve the corporate governance standards of listed companies: the nature of the corporate governance problems and the risks associated with these problems. ${ }^{29}$ By understanding the nature of corporate governance problems, policy makers can assess the need to regulate corporate governance risks through legislation or by using voluntary standards. By making a risk assessment of corporate governance problems; the particular impact that the corporate governance practices of companies can have on society at large; the significance of the impact; and the frequency with which the problems (can) occur, regulators can determine what kind of regulatory form is most desirable. For example, in EU member states the operations of nuclear power plants are strictly regulated by legislation. Although the likelihood of a nuclear accident is limited, the potential impact and the risks associated with a nuclear accident are great. Voluntary codes alone cannot be used to ensure that electricity producers adhere to strict safety standards, since the potential impact and the risks associated with malfunctions of nuclear power plants are simply too great not to regulate through legislation. 
As stated by the Australian Commonwealth Interdepartmental Committee on Quasi-Regulation (CICQR):

'As a general guide, if the risk of an event is low, and its impact is also low, then there would be little need for a strong regulatory hand by government... Conversely, if there is a high risk of a particular event occurring, and significant impacts on a national scale are likely - for example, widespread outbreaks of disease or plane crashes if minimum standards are not followed - then governments may choose to intervene to ensure standards are enforced.'30

The relationship between risks and regulatory forms is illustrated in Figure 3.

\section{CONCLUSIONS}

The relationship between corporate governance risks and regulatory forms appears to be well understood by the drafters of the Winter Report. As suggested by Figure 3, corporate failures such as Enron can be avoided only when companies are forced to comply with legislation. The great risks and impact these corporate failures have on the confidence of investors can justify the development of more stringent corporate legislation, such as the Sarbanes-Oxley Act. On the other hand, the impact of companies not complying with voluntary corporate governance codes seems not to justify more company legislation in many EU member states. Indeed, the controversial findings on the impact of corporate governance standards on the financial performance of corporations and the absence of quantifiable data seem to support the Winter Report's approach: to refrain from further legislative intervention. In fact, the Winter Report clearly states that the market is the right place to enforce compliance with standards propagated by most voluntary corporate governance codes. The risks associated with non-compliance with voluntary corporate governance codes are too small to justify further legislation.

Given the results of this study, a great majority of Europe's leading companies are not yet too concerned about non-compliance with voluntary codes and apparently also do not understand the competitive advantages of setting greater corporate governance standards. Only a minority of leading companies has discovered compliance to be a valuable tool to improve reputation, to increase the value of a company's assets and to improve investor perception.

Judgments must be made by each company to assess the risks associated with non-compliance with voluntary corporate governance codes and the impact such behaviour might have on the company's reputation within the investment community. Compliance with legislation does not by itself lead to a competitive advantage, since all companies in the EU are expected to do so. Compliance with voluntary corporate governance codes, however, can be a competitive advantage. The recommendations of the Winter Report and the EU corporate governance action plan give European companies this choice.

\section{References}

1 Report of the High Level Group of Company Law Experts on a Modern Regulatory Framework for Company Law in Europe and the press release of the High Level Group of Company Law Experts (November 2002), both at www.europa. eu.int/comm/internal_market.

2 European Union (2003) Modernising Company Law and Enhancing Corporate Governance in the European Union - A Plan to Move Forward, EU Action Plan, available at www.europa.eu.int/comm/internal_market.

3 Ref. 1 above, 5.

4 A comprehensive overview of corporate governance codes is available on the website of the European Corporate Governance Institute (www.ecgi.org). 
5 See also, for an overview of corporate governance codes in Europe: Gregory, $\mathrm{H}$. (2002) Comparative Study of Corporate Governance Codes Relevant to the European Union and its Member States, available at www. europa.eu.int/comm/internal_market.

6 Maassen, G. F. (2003) Handbook of Corporate Governance [in Dutch], Kluwer Publishers, Deventer, the Netherlands.

7 See The Financial Aspects of Corporate Governance, Committee set up by the Financial Reporting Council, the London Stock Exchange and the accountancy profession, 1st December, 1992 at www. ecgi.org.

8 Maassen (2003), ref. 6 above; and Greenbury Report, Study Group on Directors' Remuneration set up by the CBI, 17th July, 1995 at www.ecgi.org.

9 Viénot I Report, Conseil National du Patronat Français (CNPF) and Association Française des Entreprises Privées (AFEP), July, 1995 at www.ecgi.org.

10 See the Spanish Círculo de Empresarios, October, 1996 at www.ecgi.org.

11 Peters Report and Recommendations, Corporate Governance in the Netherlands, Committee on Corporate Governance, 27th June, 1997; Cardon Report, Belgian Corporate Governance Commission, 1998; the Viénot II Report, Mouvement des Entreprises de France (MEDEF) [formerly CNPF] and Association Française des Enterprises Privées (AFEP), July, 1999; and Corporate Governance: Swiss Code of Best Practice, Swiss Business Federation, 25th July, 2002 at www.ecgi.org.

12 Urgent Recommendations Concerning Corporate Governance, Japan Federation of Economic Organisations (Keidanren), September, 1997; Desirable Corporate Governance in India - A Code, Confederation of Indian Industry; the Korean Code of Best Practice for Corporate Governance, Committee on Corporate Governance, September 1999; and the Malaysian Code on Corporate Governance, Securities Commission Malaysia, March 2000 at www.ecgi.org.

13 The Forum for Corporate Governance in Indonesia (FCGI) is the leading NGO in
Indonesia advocating modern corporate governance standards. The Forum organised the first national corporate-governance conference in Indonesia in January 2003. For more information see www.fcgi.or.id.

14 Maassen, ref. 6 above.

15 The OECD, USAID, the EBRD and the IFC sponsor and implement various technical assistance projects to improve the enabling environment and the corporate governance standards in developing countries.

16 Despite the development of the Russian Corporate Governance Code and the new Russian Law on Joint Stock Companies, the arrest in July 2003 of Mr Lebedev, chairman of Menatep, the finance group which controls 61 per cent of oil giant Yukos, and the arrest in October 2003 of Mikhail Khodorkovsky, the CEO of Yukos, Russian capital markets are again struggling to survive. For more information on corporate governance in Russia, see the website of the Russian Investor Protection Association: www.corp-gov.org.

17 See The Corporate Governance Code for Polish Listed Companies (final proposal), The Polish Corporate Governance Forum, June 2002. An example of a recent initiative to develop corporate governance standards in the Balkans with the assistance of the international community is the USAID Macedonia Corporate Governance and Company Law Project (www.maccorpgov. com.mk).

18 See The Combined Code on Corporate Governance, The Financial Reporting Council (FRC), 23th July, 2003; Audit Committees - Combined Code Guidance (the Smith Report), a report and proposed guidance by a Financial Reporting Council appointed group chaired by Sir Robert Smith; and the Review of the Role and Effectiveness of Non-Executive Directors, Department of Trade and Industry, 20th January, 2003.

19 OECD (1999) Principles on Corporate Governance, Paris. A review of the OECD principles is expected in 2004: www. ecgi.org. 
20 Ref. 1 above, 72.

21 Cuervo, A. (2002) 'Corporate governance mechanisms: A plea for less code of good governance and more market control', International Corporate Governance, 10, 2.

22 Mallin, C. (2001) 'Institutional investors and voting practices: An international comparison', International Corporate Governance, $\mathbf{9}, 2$.

23 APCIMS-EASD Corporate Governance Committee (2002) Shareholder Rights, A Legal Comparison, European Association of Securities Dealers, Brussels, Belgium at www.easd.com.

24 Whittington, G. (1993) 'Corporate governance and the regulation of financial reporting', Accounting and Business Research, 91A, 311-319.

25 Finch, V. (1994) 'Corporate governance and Cadbury: Self-regulation and alternatives', Journal of Business Law, January, 51-62.

26 See, for compliance reports: Conyon, M. J. (1994) 'Corporate governance changes in the United Kingdom', Corporate Governance: An International Review, 2, 87-99; Conyon, M. J. and Mallin, C. A. (1997) 'A review of compliance with Cadbury', Journal of General Management, 2, 24-37; Cadbury Committee (1995) Report of the Committee on the Financial Aspects of Corporate Governance: Compliance with the Code of Best Practice, Gee Publishing, London; De Jong, A., De Jong, D. V., Mertens, G. and Wasley, C. (2000) The Role of Self-Regulation in Corporate Governance: Evidence from the Netherlands, Simon Graduate School of Business Administration, University of Rochester (www.ecgi.org); Stiles, P. and Taylor, B. (1993a) 'Benchmarking corpor- ate governance: The impact of the Cadbury Code', Long Range Planning, 26, 61-71; Stiles, P. and Taylor, B. (1993b) 'Benchmarking corporate governance: An update', Long Range Planning, 26, 138-139; and Peasnell, K., Pope, P. and Young, S. (1998) 'A new model', Accountancy, 122, 91.

27 For studies on the relationship between corporate governance and the financial performance of corporations: Patterson, J. (2002) The Patterson Report (www. thecorporatelibrary.com); Maassen, G. F. (1999) An International Comparison of Corporate Governance Models, Spencer Stuart, Amsterdam (www.corpgov.biz); Dalton, R. D., Daily, C. M., Ellstrand, A. E. and Johnson, J. L. (1998) 'Meta-analytic reviews of board composition, leadership structure, and financial performance', Strategic Management Journal, 19, 269-290; and Donaldson, L. and Davis, J. H. (1994) 'Boards and company performance - Research challenges the conventional wisdom', Corporate Governance: An International Review, 2, 151160.

28 Bhagat, S. and Black, B. (1997) Do Independent Directors Matter? Presented at a conference on 'The Power and Influence of Pension and Mutual Funds', New York University Salomon Center, Stern School of Business.

29 Commonwealth Interdepartmental Committee on Quasi-Regulation (CICQR), Australia (1997) Grey-Letter Law (a report of the CICQR), available at http:// www.pc.gov.au/orr/reports/external/ greyletterlaw.

30 Ibid., 51.

31 Ibid., 52. 